Goldschmidt 2021 Abstract

https://doi.org/10.7185/gold2021.5512

\section{Scheelite trace element composition: Magmatic versus metamorphic hydrothermal deposits}

\author{
KAIRAN LIU, ZHAOSHAN CHANG AND SHIQIANG \\ HUANG
}

Colorado School of Mines

Presenting Author: 1kr.sasa@gmail.com

Some quartz-vein-dominant style deposits and skarns have ambiguous origins regarding whether they are magmatic or metamorphic hydrothermal. In this study, we use scheelite trace elements to distinguish the two major types. The composition of scheelite from six magmatic-hydrothermal deposits and eight metamorphic-hydrothermal deposits has been analyzed via LAICP-MS. We also collected scheelite trace element data from 35 publications on 71 deposits with unequivocal genesis classification. Together a database with 3259 LA-ICP-MS analyses from 85 deposits are established. It has been found that generally, magmatic-hydrothermal scheelite is relatively enriched in Mo (10-100,000 ppm), $\mathrm{Nb}(1-2,000 \mathrm{ppm})$ and $\mathrm{Ta}$ $(0.02-1,000 \mathrm{ppm})$, depleted in $\mathrm{Sr}(<1,000 \mathrm{ppm})$, and has low calculated $\mathrm{Eu}$ anomaly values $\left(\mathrm{Eu}_{\mathrm{A}}=0.1-10\right)$. By contrast, metamorphic-hydrothermal scheelite is depleted in Mo $(<100$ $\mathrm{ppm}), \mathrm{Nb}(<30 \mathrm{ppm})$ and $\mathrm{Ta}(<5 \mathrm{ppm})$, contains abundant $\mathrm{Sr}$ (200-10,000 ppm), and has higher Eu anomalies $\left(1<\mathrm{Eu}_{\mathrm{A}}<100\right)$. These chemical differences in scheelite were used to construct a discriminant diagram to distinguish the fluid source: $\mathrm{Mo}^{*}$ $\left(\mathrm{Nb}+\mathrm{Ta}\right.$ ) versus $\mathrm{Sr}^{*} \mathrm{Eu}_{\mathrm{A}}$ (Fig. 1), which involves data of 59 deposits ( $\mathrm{Nb}$ and $\mathrm{Ta}$ are not reported for some deposits).

The diagram separates 53 of the 59 deposits, indicating an effectiveness of $\sim 90 \%$. All the 31 orogenic deposits plot in the metamorphic-hydrothermal domain, and 22 out of the 28 skarns and greisens plot in the magmatic-hydrothermal domain. The remaining six magmatic-hydrothermal deposits have data points plotted on both sides of the boundary (Fig. 1). The data points plotted over the border are scheelite hosted in quartz veins at distal locations and/or formed later in the paragenesis. It is speculated that the magmatic-hydrothermal fluids changed composition over time through temperature decrease, mixing with groundwater and/or interacting with the wall rocks, which caused the precipitation of $\mathrm{Nb}$, Ta and Mo at proximal locations and the addition of $\mathrm{Sr}$ and $\mathrm{Eu}$ from leaching the wallrocks. Overall, scheelite geochemistry is a new tool in the toolbox to distinguish magmatic vs. metamorphic hydrothermal deposits.

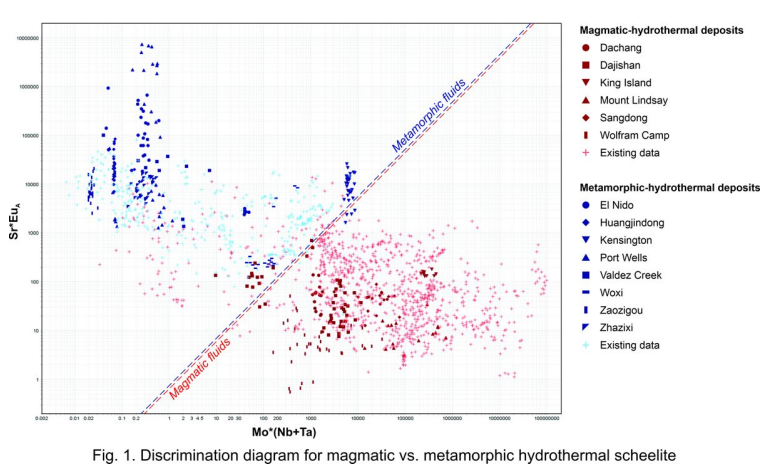

